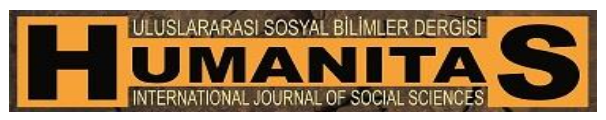

$\begin{array}{ll}\text { Humanitas, 2017; 5(9): 231-246 } & \text { http://humanitas.nku.edu.tr } \\ \text { ISSN: } 2147-088 X & \text { DOI: } \underline{10.20304 / \text { humanitas.320723 }}\end{array}$

Araştırma-İnceleme

\title{
TEKİRDAĞ BÜYÜKŞEHİR NAİP KÖYÜ ÜZERİNE BİR SOSYAL YAPI ARAŞTIRMASI
}

\section{Coşkun DİKBIYIK ${ }^{1}$ \\ Ensar YILMAZ ${ }^{2}$}

\begin{abstract}
Öz: Naip köyü, Tekirdağ ili merkez ilçesi olan Süleymanpaşa’ya bağlı bir merkez köy olma özelliği taşımaktadır. Bu bağlamda araştırmanın evreni Naip Köyü, araştırmanın kapsamı ise Naip Köyü'ndeki toplumsal ilişkilerin yapısallığının ölçümüdür. Nüfusu 487 olan köyde 93 kişi ile yüz yüze mülakat yöntemi ve anket formları ile toplanan veriler Excell programında sınıflandırılmış ve tablolar oluşturularak anlamlı sonuçlar ortaya koyulmaya çalışılmıştır. Araştırma bulguları kısaca şöyle özetlenebilir. Ağırlıklı olarak orta ve üst yaş grubunun yaşadığı köyde çocuk sayısı sınırlıdır. Mesleki dağılım bakımından daha çok çiftçilik ve köy koşullarına göre belli oranda esnaflık önde gelmektedir. Aile ilişkileri bağlamında flörte olumlu bakılmaktadır. Boşanma oranları köy ortamına göre büyük artış göstermektedir. Ailede karar alma sürçlerine katılmada öncelikli olarak baba ve sonra da anne etkin görünmektedir. Gelir düzeyi köy şartları çerçevesinde alt ve orta seviyededir. Alış veriş biçimi büyük bir çoğunlukla nakde dayanmaktadır Köylüler geleceğe ilişkin kaygılar taşımakla birlikte çoğunlukla durumlarından memnun gözükmektedirler. Gündelik hayatlarının büyük bir bölümünü işe ayıran köylüler için TV, önemli ölçüde boş vakitlerini değerlendirdikleri bir araç olarak işlev görmektedir. Köylülerin çoğunluğu ilkokul mezunu olup, tamamına yakını okuryazardırlar. Avrupa birliğine girişimiz ile ilgili olarak pek ümitli değildirler. Dini yaşayış bakımından bazı eksikleri olsa da dini duyarlılığa sahiptirler. Bütün bunların yanında köylülerin büyük bir çoğunluğu köylerinde yaşamaktan memnundurlar. Bunda köyün, yöresel ürünlerin sergilendiği bir pazar yeri hüviyeti taşımasının getirdiği prestij ve avantajların da önemli bir rolü olduğu söylenebilir. Köy kentleşme süreci içinde bazı etkileşimler yasamakla beraber geleneksel yapı
\end{abstract}

\footnotetext{
${ }^{1}$ Yrd. Doç. Dr., Namık Kemal Üniversitesi, Fen-Edebiyat Fakültesi, Sosyoloji Bölümü. cdikbiyik@nku.edu.tr

${ }^{2}$ Yrd. Doç. Dr., İstanbul Medeniyet Üniversitesi, Sağlık Bilimleri Fakültesi, Sosyal Hizmet Bölümü. ensar.yilmaz@medeniyet.edu.tr
} 
özelliklerini büyük ölçüde devam ettirmekte ve sonuçta kente yeterince eklemlenememektedir.

\title{
Anahtar Sözcükler: Sosyal Yapı, Köy, Naip Köyü, Tekirdağ. \\ A RESEARCH ON SOCIAL STRUCTURE OF NAIP VILLAGE FROM TEKİRDAĞ METROPOLITAN MUNICIPALITY
}

\begin{abstract}
Naip is a central village of Süleymanpaşa district of Tekirdağ province. Number of children is limited which is typicalfor western part of Turkey. Distribution of age among population is generally middle and old ages. Their subsistence conditions are based on agricultural activities and commerce to a limited extent. Divorce rates are increasing according to average village divorce rates in recent times. They view the flirt relations positively. Decision maker in the family is generally father and sometimes mother. Their income level is middle and low. Their shopping activities are based on cash. Almost all of them are satisfied about their situation despite their anxieties about future. They allocate most of their time for work and television is a tool for their leisure time. Almost all of them are literate and primary school graduate. They are not hopeful about our being a member of European Union. They have some deficiencies but have a considerable level of religious sentiments. In addition, because Naip Village is a satisfactory place in socio-economic terms and it is a marketplace where several visitors come to buy organic and traditional village products. It can preserve its specific social structure to a great extent.
\end{abstract}

Keywords: Social Structure, Village, Naip Village, Tekirdağ.

\section{Giriş}

Kentleşme süreciyle birlikte kentsel yapılarda meydana gelen toplumsal, kültürel, siyasal ve ekonomik kökenli gelişmeler bu alanda ciddi çalışmalara ihtiyaç olduğunu göstermektedir (Karakaş, 2007: 2). Bununla birlikte kentlerde yaşanan bu değişimin köylerde nasıl cereyan ettiği de incelenmesi gereken aynı derecede öneme sahip bir olgu olarak karşımıza çıkmaktadır.

Toplumsal yapı araştırmalarıyla maruf sosyolog Mübeccel Kıray, toplumun ne olduğu değil, ne tür temel özellikleri taşıdığı önemlidir, der. $\mathrm{Bu}$ temel özelliklerden bir tanesi toplumun yerleştiği arazi diğeri ise arazinin üzerindeki nüfus ve nüfusun özellikleridir (Kiray, 2006,s. 312).

Sosyoloji sözlüğünde toplumsal yapı şöyle tanımlanmaktadır: “...bir toplumun dinsel, ekonomik, siyasal ve diğer kurumlarının onun toplumsal yapısını meydana getirdiği, bu yapının bileşenlerinin de normlar, değerler ve toplumsal rollerden oluştuğu söylenebilir (Marshall, 1999, s. 804). Radcliffe-Brown ise, toplumsal yapıyı kişiler arası ilişkiler olarak görmektedir (aktaran Gökçe, 2004, s. 2). Toplumsal yapı, bir yandan farklılaşmaya işaret ettiği gibi, bir yandan da sürekliliği ifade eder (Fichter, 2002, s. 83). Aynı zamanda sosyal yapı bir yandan kişilerin doğrudan doğruya tecrübelerine ve yaşantılarına dayanırken, diğer yandan insanlar arası ilişkilerden bütünlüğünün varlığına ulaşır (Bozkurt, 1972, s. 40). 
Toplumsal yapı çalışmaları, Türkiye'nin toplumsal yapısı olarak ele alınabileceği gibi bir kentin, bir köyün toplumsal yapısı biçiminde de ele alınabilir. Bununla birlikte bu farklı düzeyler arasında geçişkenliklerin ve farklılaşmaların olacağı da tabiidir (Yılmaz-Avc1, 2012, s. 4).

Toplumsal yapı araştırmaları bir yönüyle toplumun bütününü diğer yönüyle köy, kasaba ve kent gibi farklı yerleşim birimlerini içeren ve bu çerçevede derinliğine değerlendirmeler gerektiren monografik çalışmalara da kaynaklık eden analiz biçimleridir. Bu konuda dünyada, özellikle de Batı Avrupa ve Amerika'da pek çok araştırmaya rastlanmaktadır. Ülkemizde de bu tür araştırma ve incelemeler yapılmıştır. Özellikle kentleşme sürecinin köyleri de kapsayacak düzeyde yeni ve farklı boyutlarda gelişim göstermesi bu çerçevedeki alan araştırmalarının önemini gündeme getirmektedir.

Bu bağlamda ele aldığımız Tekirdağ ili, Süleymanpaşa İlçesindeki Naip Köyü Sosyal Yapı Araştırması bu amaca ilişkin bir çabanın ürünü olarak değerlendirilebilir. Bu araştırmada Naip Köyü halkının sosyal yapıyı oluşturan temel boyutlar üzerindeki görüş, eğilim ve tepkilerinin ortaya konmasına çalışılmıştır. Araştırma sonucunda ortaya çıkan bulguların 2014 yılında Büyükşehir statüsü kazanan Tekirdağ ilinin yönetim politikalarına da işı tutacak bir niteliğe sahip olacağını umuyoruz. Bu anlamda araştırma akademik dünyaya belli bir katkı sunmasının yanında diğer il ve ilçelere de bu çerçevede yol gösterici olacaktır.

Naip köyü Tekirdağ merkezine $14 \mathrm{~km}$ uzaklıktadır. Tekirdağ'ın en büyük mahallesi ve en yakın köylerindendir. Nüfusu 487'dir.Büyük bir çoğunluğu mübadele sonucu yerleştirilen göçmenlere dayanır. Mahallenin iklimi, Marmara iklimi etki alanı içerisindedir. Ekonomisi tarım ve hayvancıllğga dayanır. Buna bağlı olarak geleneksel ürünlerin sergilendiği merkezi bir pazar konumundadır. Altyapı olarak Mahallede ilköğretim okulu, içme suyu şebekesi, kanalizasyon şebekesi, sağlık ocağı ve sağlık evi vardır. Mahalleye ulaşımı sağlayan yol asfalt olup mahallede elektrik ve sabit telefon vardır. Ayrıca Köyde Tekirdağ' $ı$ 50 yıllık su ihtiyacını karşılayacağı öne sürülen baraj inşaatı yapımı sürmektedir.

\section{Yöntem}

Naip Köyünün sosyo-demografik, kültürel, ailevi, ekonomik ve dinsel yap1 özelliklerini tespit etmek amacıyla yaptığımız bu araştırmada halen Naip Köyünde yaşayanlar baz alınmıştır. Bu yönüyle araştırmanın evrenini Naip köyü sakinleri oluşturmaktadır. Araştırmanın amacına bağlı olarak ulaşılmak istenen örneklem birimi Naip köyünde oturan 15 yaş ve üstü kadın ve erkeklerden oluşmaktadır. Bu çerçevede araştırmamız için 93 kişi örneklem olarak seçilmiştir. Araştırmada veriler yüz yüze görüşme ve anket yöntemi kullanılarak toplanmıştır. Dolayısıyla araştırma konuya ilişkin hazırlanan anket soruları ve bu çerçevedeki gözlem ve mülakat verilerine dayanmaktadır. Araştırmada temel olarak basit yansız örnekleme yöntemi kullanılmıştır. Anket ve mülakat 2016 yılının Mayıs ayında NKÜ Fen-Edebiyat Fakültesi Sosyoloji 
Dikbıyık, C. ve Yılmaz, E. (2017).Tekirdağ Büyükşehir Naip Köyü Üzerine Bir Sosyal Yapı Araştırması. Humanitas, 5(9), 231-246

Bölümü 3.sınıf öğrencilerinin de katkısıyla uygulanmıştır. Anket uygulanan kişilerin anket sorularını ciddiye aldıkları ve sorulara kendi açılarından doğru yanıtlar verdikleri gözlemlenmiştir. Anket yolu ile toplanmış olan veriler Microsoft Excel programı aracılığı analiz edilmiştir. Araştırmada veriler kümelenerek yorumlanmıştır. $\mathrm{Bu}$ bağlamda konu üç başlık halinde ele alınmıştır. Bunlar;

1. Sosyo-demografik durum ve aile

2. Ekonomi

3. Eğitim- kültür

Araştırmada her ne kadar 93 kişi örneklem olarak seçilmişse de anket uygulanırken bazı sorulara verilecek cevaplar iki veya daha fazla şıkkın işaretlenmesine olanak tanındığından, bazı soruların cevapları 93 'ten daha fazla çıkmıştır.

\section{Sosyo-Demografik Durum ve Aile}

Tablo 1: Cinsiyete Göre Dă̆glım

\begin{tabular}{|l|l|l|}
\hline Cinsiyete Göre Dağılım & Kişi Sayısı & Yüzde \\
\hline Kadın & 45 & 48.38 \\
\hline Erkek & 48 & 51.61 \\
\hline Toplam & $\mathbf{9 3}$ & $\mathbf{1 0 0}$ \\
\hline
\end{tabular}

Araştırmaya dahil edilen kişilerin cinsiyete göre yüzdelik oranı \%49 kadın ve \%51 erkek olarak dengeli bir dağılım sağlanmıştır.

Tablo 2: Medenî Duruma Göre Dă̆llım

\begin{tabular}{|l|l|l|}
\hline $\begin{array}{l}\text { Medeni Duruma } \\
\text { Göre Dağılım }\end{array}$ & $\begin{array}{l}\text { Kişi } \\
\text { Sayısı }\end{array}$ & Yüzde \\
\hline Evli & 64 & 68.81 \\
\hline Bekar & 12 & 12.90 \\
\hline Dul & 15 & 16.12 \\
\hline Boşanmış & 2 & 2.15 \\
\hline Nişanlı/Sözlü & 0 & 0 \\
\hline Toplam & $\mathbf{9 3}$ & $\mathbf{1 0 0}$ \\
\hline
\end{tabular}

Yine araştırmaya dahil edilenlerin \%69'a varan bir oranda evli, \%13 bekar, \%16's1 dul, \%2'si ise boşanmıştır.

Tablo 3: Çocuk Sayısına Göre Dağılım

\begin{tabular}{|l|l|l|}
\hline $\begin{array}{l}\text { Çocuk Sayısına } \\
\text { Göre Dağılım }\end{array}$ & $\begin{array}{l}\text { Kişi } \\
\text { Sayısı }\end{array}$ & Yüzde \\
\hline
\end{tabular}


Dikbıyık, C. ve Yılmaz, E. (2017).Tekirdağ Büyükşehir Naip Köyü Üzerine Bir Sosyal Yapı Araştırması. Humanitas, 5(9), 231-246

\begin{tabular}{|l|l|l|}
\hline Çocuk yok & 18 & 19.35 \\
\hline 1 & 6 & 6.45 \\
\hline 2 & 36 & 38.70 \\
\hline 3 & 16 & 17.20 \\
\hline Daha fazla & 17 & 18.27 \\
\hline Toplam & $\mathbf{9 3}$ & $\mathbf{1 0 0}$ \\
\hline
\end{tabular}

Köyde ağırlıklı olarak ailelerin 2 ve üzeri çocuğa sahip oldukları tespit edilmiştir.

Tablo 4: Yaşa Göre Dă̆ılım

\begin{tabular}{|l|l|l|}
\hline $\begin{array}{l}\text { Yaşa Göre } \\
\text { Dağılım }\end{array}$ & $\begin{array}{l}\text { Kişi } \\
\text { Sayısı }\end{array}$ & Yüzde \\
\hline $15-25$ & 4 & 4.30 \\
\hline $25-35$ & 11 & 11.82 \\
\hline $35-45$ & 12 & 12.90 \\
\hline $45-55$ & 22 & 23.65 \\
\hline 55 ve üstü & 44 & 47.31 \\
\hline Toplam & $\mathbf{9 3}$ & $\mathbf{1 0 0}$ \\
\hline
\end{tabular}

Araştırmadaki örneklem ağırlıklı olarak orta ve üstü yaş grubundadır. Bu durum günümüz köy demografik yapısına da uygun düşmektedir.

Tablo 5: Mesleklere Göre Dă̆glım

\begin{tabular}{|l|l|l|}
\hline Meslek & Kişi Sayısı & Yüzde \\
\hline Esnaf & 11 & 10.67 \\
\hline Ev Hanımı & 36 & 34.95 \\
\hline İşçi & 4 & 3.88 \\
\hline Memur & 3 & 2.91 \\
\hline Çiftçi & 26 & 25.24 \\
\hline Özel Şirket Çalışanı & 2 & 1.94 \\
\hline İşsiz & 3 & 2.91 \\
\hline Diğer & 18 & 17.47 \\
\hline Toplam & $\mathbf{1 0 3}$ & $\mathbf{1 0 0}$ \\
\hline
\end{tabular}


Dikbıyık, C. ve Yılmaz, E. (2017).Tekirdağ Büyükşehir Naip Köyü Üzerine Bir Sosyal Yapı Araştırması. Humanitas, 5(9), 231-246

Köydeki mesleki dağılımın \%10 civarında esnaf, \%35 oranında ev hanımı ve $\% 25$ oranında da çiftçi olarak belirmesi kentleşme sürecinde geleneksel mesleki köy özelliklerinin büyük ölçüde korunduğunu göstermesi bakımından anlamlidir.

Tablo 6: Eşs ile Tanışma Şekillerine Göre Dağılım

\begin{tabular}{|l|l|l|}
\hline Tanışma Şekli & Kişi Sayısı & Yüzde \\
\hline $\begin{array}{l}\text { Kendi Kendine } \\
\text { Tanışarak }\end{array}$ & 48 & 50.52 \\
\hline Görücü Usulü ile & 28 & 29.47 \\
\hline Tanıdık Aracılığı ile & 5 & 5.26 \\
\hline İnternet Aracılığı ile & 0 & 0 \\
\hline Diğer & 14 & 14.73 \\
\hline Toplam & $\mathbf{9 5}$ & $\mathbf{1 0 0}$ \\
\hline
\end{tabular}

Eş ile tanışma şekillerinin \%50 civarında kendi kendine tanışarak, \%30 oranında da görücü usulü ile çıkması köydeki insan ilişkileri profilini göstermesi bakımından anlamlı bulunmuştur. Bu tutum köylülerin evlilik öncesi tanışma hakkındaki görüşlerine de yansımaktadır.

Tablo 7: Evlilik Öncesi Tanışma Hakkındaki Görüşlere Göre Dağıllım

\begin{tabular}{|l|l|l|}
\hline $\begin{array}{l}\text { Tanışma Hakkındaki } \\
\text { Görüşler }\end{array}$ & Kişi Sayısı & Yüzde \\
\hline Gereksiz Görüyorum & 7 & 7.60 \\
\hline Olumsuz Bakıyorum & 14 & 15.21 \\
\hline Olumlu Bakıyorum & 55 & 59.78 \\
\hline Ahlaki Bulmuyorum & 4 & 4.34 \\
\hline Gerekli Görüyorum & 12 & 13.04 \\
\hline Toplam & $\mathbf{9 2}$ & $\mathbf{1 0 0}$ \\
\hline
\end{tabular}

Evlilik öncesi tanışmanın \%60 oranında olumlu ve \%13 oranında gerekli görülmesi, toplamda $\% 73$ oranında evlilik öncesi tanışmanın, başka bir anlamda flörtün diğer bölgelere oranla büyük ölçüde olumlandığını göstermektedir.

Tablo 8: Yakın Akrabalarda Boşanan Kişi Olması Durumuna Göre Dağılım

\begin{tabular}{|l|l|l|}
\hline $\begin{array}{l}\text { Boşanan Kişi Olması } \\
\text { Durumu }\end{array}$ & Kişi Sayısı & Yüzde \\
\hline Evet Var & 42 & 44.21 \\
\hline
\end{tabular}


Dikbıyık, C. ve Yılmaz, E. (2017).Tekirdağ Büyükşehir Naip Köyü Üzerine Bir Sosyal Yapı Araştırması. Humanitas, 5(9), 231-246

\begin{tabular}{|l|l|l|}
\hline Hayır Yok & 53 & 55.78 \\
\hline Toplam & $\mathbf{9 5}$ & $\mathbf{1 0 0}$ \\
\hline
\end{tabular}

Yakın akrabalardaki boşanma oranının $\% 44$ oranında çıkması, Türkiye genelinde boşanma oranlarının son zamanlarda önemli bir artış göstermesi yanında evlilik öncesi flört ilişkilerinin evliliğe yönelik olarak yeteri kadar sağlam temellere dayalı olarak gerçekleşmediğini de göstermektedir.

Tablo 9: Şahit Olan Boşanmaların En Önemli Durumuna Göre Dağılım

\begin{tabular}{|l|l|l|}
\hline En Önemli Neden & Kişi Sayısı & Yüzde \\
\hline Ailelerin Müdahalesi & 2 & $\mathbf{2 . 6 6}$ \\
\hline $\begin{array}{l}\text { İçki-Kumar } \\
\text { Alışkanlıkları }\end{array}$ & 8 & $\mathbf{1 0 . 6 6}$ \\
\hline Şiddetli Geçimsizlik & 25 & \\
\hline Ekonomik Nedenler & 6 & $\mathbf{3 3 . 3 3}$ \\
\hline Cinsel Nedenler & 2 & $\mathbf{8}$ \\
\hline Dayak & 5 & $\mathbf{2 . 6 6}$ \\
\hline Aldatma & 4 & $\mathbf{6 . 6 6}$ \\
\hline Anlaşmalı Ayrılma & 4 & $\mathbf{5 . 3 3}$ \\
\hline Diğer & 19 & $\mathbf{5 . 3 3}$ \\
\hline Toplam & $\mathbf{7 5}$ & $\mathbf{2 5 . 3 3}$ \\
\hline
\end{tabular}

Boşanma nedenleri olarak şiddetli geçimsizliğin \%33 oranında çıkması yukarıdaki flört ilişkilerinin evliliğe yönelik olarak yeteri kadar sağlam temellere dayalı olarak geliştirilemediği şeklindeki savımızı güçlendirmektedir. Boşanma nedeni olarak \%10.66 oranına içki-kumar alışkanlıkları ve \%6.66 oranında da dayak seçenekleri anlamlı bulunmuştur.

Tablo 10: Aileyi Illgilendiren Konularda Kararları Alana Kişilere Göre Dağılım

\begin{tabular}{|l|l|l|}
\hline $\begin{array}{l}\text { Kararları Alan } \\
\text { Kişiler }\end{array}$ & Kişi Sayısı & Yüzde \\
\hline Baba Tek Başına & 30 & $\mathbf{3 2 . 2 5}$ \\
\hline Anne Tek Başına & 14 & $\mathbf{1 5 . 0 5}$ \\
\hline Büyük Ağabey & 2 & $\mathbf{2 . 1 5}$ \\
\hline Anne Baba Birlikte & 28 & $\mathbf{3 0 . 1 0}$ \\
\hline Diğer Aile Büyükleri & 0 & $\mathbf{0}$ \\
\hline
\end{tabular}


Dikbıyık, C. ve Yılmaz, E. (2017).Tekirdağ Büyükşehir Naip Köyü Üzerine Bir Sosyal Yapı Araştırması. Humanitas, 5(9), 231-246

\begin{tabular}{|l|l|l|}
\hline $\begin{array}{l}\text { Tüm Aile Büyükleri } \\
\text { Birlikte }\end{array}$ & 5 & $\mathbf{5 . 3 7}$ \\
\hline $\begin{array}{l}\text { Tüm Aile Üyeleri } \\
\text { Birlikte }\end{array}$ & 13 & $\mathbf{1 3 . 9 7}$ \\
\hline Evin Erkekleri & 1 & $\mathbf{1 . 0 7}$ \\
\hline Toplam & $\mathbf{9 3}$ & $\mathbf{1 0 0}$ \\
\hline
\end{tabular}

Aileyi ilgilendiren konularda karar alma biçimlerinde tek başına baba \%32.25, tek başına anne \%15.05 anne baba birlikte \%30.10, tüm aile bireyleriyle birlikte \%13.97 oranında çıkması, ailede geleneksel ataerkil yapının etkili olduğu, başka bir ifadeyle anne babanın kararlarda etkin olduğu, diğer aile üyelerine karar alma süreçlerinde yeterince söz hakkı verilmediği anlaşılmaktadır.

\section{Ekonomi}

Tablo 11 : Gelir Durumuna Göre Dă̆ılım

\begin{tabular}{|l|l|l|}
\hline Gelir Durumu & Kişi Sayısı & Yüzde \\
\hline 500 TL ve Altı & 17 & 18.47 \\
\hline $500-999$ TL & 30 & 32.60 \\
\hline $1000-1999$ TL & 26 & 28.26 \\
\hline $2000-2999$ TL & 14 & 15.21 \\
\hline 3000 TL ve Üstü & 5 & 5.43 \\
\hline Toplam & $\mathbf{9 2}$ & $\mathbf{1 0 0}$ \\
\hline
\end{tabular}

Köy sakinlerinin gelir düzeyi bakımından yarı yarıya orta ve alt seviyelerde olduğu düşünülebilir.

Tablo 12: Ekonomik Durumdan Memnuniyete Göre Dă̆glım

\begin{tabular}{|l|l|l|}
\hline $\begin{array}{l}\text { Ekonomik Durumdan } \\
\text { Memnuniyet }\end{array}$ & Kişi Sayısı & Yüzde \\
\hline Çok Memnunum & 5 & 5.37 \\
\hline Memnunum & 51 & 54.83 \\
\hline Memnun Değilim & 19 & 20.43 \\
\hline Hiç Memnun Değilim & 18 & 19.35 \\
\hline Toplam & $\mathbf{9 3}$ & $\mathbf{1 0 0}$ \\
\hline
\end{tabular}

Köy sakinlerinin ekonomik durumdan \%60 oranında memnun, \%40 oranında memnuniyetsiz olduğu görülmektedir. 
Dikbıyık, C. ve Yılmaz, E. (2017).Tekirdağ Büyükşehir Naip Köyü Üzerine Bir Sosyal Yapı Araştırması. Humanitas, 5(9), 231-246

Tablo 13: Türkiye Şartlarına Göre Ailenin Geliri Hakkındaki Görüşlere Göre Dă̆llım

\begin{tabular}{|l|l|l|}
\hline $\begin{array}{l}\text { Ailenin Geliri } \\
\text { Hakkındaki Görüsşler }\end{array}$ & Kişi Sayısı & Yüzde \\
\hline Çok Düşük & 18 & $\mathbf{1 9 . 5 6}$ \\
\hline Alt & 15 & $\mathbf{1 6 . 3 0}$ \\
\hline Orta & 46 & $\mathbf{5 0}$ \\
\hline Ortanın Üstü & 12 & $\mathbf{1 3 . 0 4}$ \\
\hline Üst & 1 & $\mathbf{1 . 0 8}$ \\
\hline Üstün Üstü & 0 & $\mathbf{0}$ \\
\hline Toplam & $\mathbf{9 2}$ & $\mathbf{1 0 0}$ \\
\hline
\end{tabular}

Ailenin gelirini \%19.56 oranında çok düşük görenlerin gelir düzeyini 500TL ve görenlerin oranıyla (\%18.47)paralel olduğu görülmektedir. Buna \%16 oranında gelirini alt düzey olarak görenleri ekleyebiliriz. Gelirini \%50 oranında orta ve $\% 13$ oranında ortanı üstü görenlerin de durumundan memnun olduğu söylenebilir. $\mathrm{Bu}$ durum gelir düzeyi ile memnuniyet oranı arasında büyük ölçüde bir korelasyon kurmamıza izin vermektedir.

Tablo 14: Alışveriş Yapma Şekline Göre Dăğlım

\begin{tabular}{|l|l|l|}
\hline Alışveriş Yapma Şekli & Kişi Sayısı & Yüzde \\
\hline Peşin & 69 & 72.63 \\
\hline Kredi Kartıyla & 10 & 10.52 \\
\hline Taksitle & 2 & 2.10 \\
\hline Veresiye & 4 & 4.21 \\
\hline Duruma Göre Farklı & 10 & 10.52 \\
\hline Toplam & $\mathbf{9 5}$ & $\mathbf{1 0 0}$ \\
\hline
\end{tabular}

Alışveriş yapma biçiminin \%72.63 oranında peşin çıkması köy halkının büyük bir çoğunlukla geleneksel pazar anlayışı içerisinde "garantici" bir tutuma sahip olduğunu göstermektedir. Henüz kredi kartıyla alışveriş yeterince rağbet görmemektedir. 
Dikbıyık, C. ve Yılmaz, E. (2017).Tekirdağ Büyükşehir Naip Köyü Üzerine Bir Sosyal Yapı Araştırması. Humanitas, 5(9), 231-246

Tablo 15: Tasarrufların Değerlendirme Şekline Göre Dağıllım

\begin{tabular}{|l|l|l|l|l|}
\hline \multicolumn{2}{|l|}{} & \multicolumn{2}{l|}{ Evet } & Hayır \\
\cline { 2 - 5 } & $\begin{array}{l}\text { Kişi } \\
\text { Sayısı }\end{array}$ & Yüzde & $\begin{array}{l}\text { Kişi } \\
\text { Sayısı }\end{array}$ & Yüzde \\
\hline Döviz Alıyoruz & 2 & & & $\mathbf{2 . 1 5}$ \\
\hline $\begin{array}{l}\text { Hazine Bonosu ya da } \\
\text { Devlet Tahvili Alıyoruz }\end{array}$ & 0 & & & $\mathbf{0}$ \\
\hline $\begin{array}{l}\text { Finans Kurumlarında } \\
\text { Katılım Hesabı } \\
\text { Açıoruz Tasarruf }\end{array}$ & 3 & & & $\mathbf{3 . 2 2}$ \\
\hline $\begin{array}{l}\text { Pek } \\
\text { Yapamıoruz }\end{array}$ & 8 & & & \\
\hline Altın Alıyoruz & 0 & & & $\mathbf{5 0 . 5 3}$ \\
\hline Hisse Senedi Alıyoruz & 0 & & & $\mathbf{8 . 6 0}$ \\
\hline Gayrimenkul Alıyoruz & 12 & & $\mathbf{0}$ \\
\hline Diğer & 21 & & & $\mathbf{2 2 . 5 8}$ \\
\hline Boş & 0 & & & $\mathbf{0}$ \\
\hline Toplam & $\mathbf{9 3}$ & & & $\mathbf{1 0 0}$ \\
\hline
\end{tabular}

Köy sakinlerinin \%50.53 oranında pek tasarruf yapmadıklarını söylemeleri, orta ve alt gelir düzeyine sahip kişilerin çoğunlukla ancak kendi gelirleriyle kendi geçimlerini sağladıkları ve tasarruf edebilecek kadar yeterli gelirleri olmadıklarını düşündürmektedir. Buna karşılık \%8.60 oranında döviz, \%12.90 oranında gayrimenkul alınması tasarrufların daha çok kendini orta görenlerin bir kısmı ile kendini ortanın üstü ve üst düzey görenler tarafindan yapıldığını düşündürmektedir.

Tablo 16: Gelecekle İlgili Bir Endişe Taşıma Durumuna Göre Dă̆ılım

\begin{tabular}{|l|l|l|}
\hline $\begin{array}{l}\text { Endişe Taşıma } \\
\text { Durumu }\end{array}$ & Kişi Sayısı & Yüzde \\
\hline Evet Taşıyorum & 52 & 55.31 \\
\hline Hayır Taşımıyorum & 42 & 44.68 \\
\hline Toplam & $\mathbf{9 4}$ & $\mathbf{1 0 0}$ \\
\hline
\end{tabular}

Gelecekle ilgili olarak \%55.31 endişe taşıyorum, \%44.68 oranında endişe taşımıyorum seçeneğinin işaretlenmesi memnuniyet ve gelir düzeyi ile ters orant1lı bir durum arzetmektedir. Arada büyük bir fark olmasa da \%55lik bir endişeli kesimin bulunması anlamlı bulunmuştur. Bu tutumun köylülerin düşük 
Dikbıyık, C. ve Yılmaz, E. (2017).Tekirdağ Büyükşehir Naip Köyü Üzerine Bir Sosyal Yapı Araştırması. Humanitas, 5(9), 231-246

ekonomik düzeyleri ile ilgili olarak geleceğe ilişkin duydukları kaygı, politik ortam ve siyasal tercihleriyle ilgili olarak geliştirdikleri tasadan kaynaklanması olasidir.

\section{Eğitim-Kültür}

Tablo 17: Eğitim Durumuna Göre Dağılım

\begin{tabular}{|l|l|l|}
\hline Eğitim Durumu & Kişi Sayısı & Yüzde \\
\hline Okur Yazar Değil & 10 & 10.75 \\
\hline İlkokul Mezunu & 63 & 67.74 \\
\hline Ortaokul Mezunu & 6 & 6.45 \\
\hline Lise Mezunu & 9 & 9.67 \\
\hline Üniversite Mezunu & 5 & 5.37 \\
\hline Lisansüstü & 0 & 0 \\
\hline Toplam & $\mathbf{9 3}$ & $\mathbf{1 0 0}$ \\
\hline
\end{tabular}

Okuryazar oranının \%90'lara ulaşması, ilkokul mezunu oranının \%67.74, Ortaokul mezunu oranının 6.45, lise mezunu oranının \%9.67, üniversite mezunu oranının \%5.37 olması ortalama köy eğitim düzeyi ve ortamıla uyumludur. Ülkemizin bazı gelişmemiş yörelerine göre daha iyi seviyede olduğu söylenebilir.

Tablo 18: Boş Zamanları Değerlendirme Biçimleri

\begin{tabular}{|l|l|l|}
\hline \multirow{2}{*}{$\begin{array}{l}\text { Boş Zamanları } \\
\text { Değerlendirme Şekli }\end{array}$} & \multicolumn{2}{|l|}{} \\
\cline { 2 - 3 } & Kişi Sayısı & Yüzde \\
\hline Televizyon Seyrederim & 51 & 31.48 \\
\hline $\begin{array}{l}\text { Kitap, Gazete, Dergi } \\
\text { Okurum }\end{array}$ & 14 & 8.64 \\
\hline Açık Havada Dolaşırım & 24 & 14.81 \\
\hline Spor Yaparım & 6 & 3.70 \\
\hline Müzik Dinlerim & 9 & 5.55 \\
\hline Parklara Giderim & 5 & 3.08 \\
\hline Seyahate Çıkarım & 6 & 3.70 \\
\hline Eğlence Yerlerine Giderim & 3 & 1.85 \\
\hline Köye Giderim & 10 & 6.17 \\
\hline Sinema veya Tiyatroya & 0 & 0 \\
\hline
\end{tabular}


Dikbıyık, C. ve Yılmaz, E. (2017).Tekirdağ Büyükşehir Naip Köyü Üzerine Bir Sosyal Yapı Araştırması. Humanitas, 5(9), 231-246

\begin{tabular}{|l|l|l|}
\hline Giderim & & \\
\hline İnternete Girerim & 2 & 1.23 \\
\hline Diğer (örgü örerim) & 32 & 19.75 \\
\hline Toplam & $\mathbf{1 6 2}$ & $\mathbf{1 0 0}$ \\
\hline
\end{tabular}

Boş zamanları değerlendirme biçimi olarak \%31.48 oranında TV seyredilmesi, \%14.81 oranında açık havada dolaşılması ve \%19.75 oranında örgü örülmesi ve diğer seçenekler köy ortamının sunduğu imkânlar dâhilinde olağan görülmelidir.

Tablo 19: Televizyon İzleme

\begin{tabular}{|l|l|l|}
\hline $\begin{array}{l}\text { Günlük Televizyon } \\
\text { Seyretme Süresi }\end{array}$ & Kişi Sayısı & Yüzde \\
\hline $0-2$ saat & 60 & 67.41 \\
\hline 3 saat & 10 & 11.23 \\
\hline 4 saat & 7 & 7.86 \\
\hline 5 saat & 6 & 6.74 \\
\hline 6 saat ve üstü & 6 & 6.74 \\
\hline Toplam & $\mathbf{8 9}$ & $\mathbf{1 0 0}$ \\
\hline
\end{tabular}

TV izleme oranının \%67.41 oranında 2 saat ile sınırlanması, diğer seçeneklerin daha düşük oranlarda seyretmesi çalışan nüfusun(tarlada, bahçede vs.) TV izlemeye çok fazla zaman ayıramaması ile açıklanabilir.

Tablo 20: Bilgisayar ve Internet Sahipliği

\begin{tabular}{|l|l|l|}
\hline $\begin{array}{l}\text { Bilgisayar Bulunma } \\
\text { Durumu }\end{array}$ & Kişi Sayısı & Yüzde \\
\hline Evet Var & 38 & 40.86 \\
\hline Hayır Yok & 55 & 59.13 \\
\hline Toplam & $\mathbf{9 3}$ & $\mathbf{1 0 0}$ \\
\hline
\end{tabular}

$\% 40.86$ oranında internetin bulunması fakat internete girme oranının $\% 1.23$ gibi çok düşük oranlarda çıkması köyün demografik yapısı ile ilgili olabilir. İnternet gibi iletişim araçlarını ve etkili bir biçimde daha çok çocuklar ve ergenlerin kullandığı, orta ve yaşlı kuşağın bilgisayar ve internet kullanımına yeterince adapte olamadığı görülmektedir. Seçilen örneklemlerin de çoğunlukla bu kuşaktan seçildiği göz önüne alınırsa bu tutumu açıklamak mümkün olur. 
Dikbıyık, C. ve Yılmaz, E. (2017).Tekirdağ Büyükşehir Naip Köyü Üzerine Bir Sosyal Yapı Araştırması. Humanitas, 5(9), 231-246

Tablo 21: Türkiye'nin Avrupa Birliği'ne Girişs Hakkındaki Görüşlere Göre Dă̆llım

\begin{tabular}{|c|c|c|}
\hline $\begin{array}{lr}\text { Avrupa } & \text { Birliği'ne } \\
\text { Giriş } & \text { Hakkındaki } \\
\text { Görüsşler } & \end{array}$ & Kişi Sayısı & Yüzde \\
\hline $\begin{array}{l}\text { Girmek İçin Gayret } \\
\text { Göstermeliyiz }\end{array}$ & 21 & 24.13 \\
\hline Bence İhtiyacımız Yok & 29 & 33.33 \\
\hline Benim İçin Fark Etmez & 24 & 27.58 \\
\hline $\begin{array}{l}\text { Türkiye'nin Zararına } \\
\text { Olacak }\end{array}$ & 3 & 3.44 \\
\hline $\begin{array}{l}\text { Zaten } \\
\text { Almayacaklar }\end{array}$ & 5 & 5.74 \\
\hline $\begin{array}{lr}\text { Ekonomi } & \text { ve } \\
\text { Özgürlükler } & \text { İçin } \\
\text { Faydalı } & \end{array}$ & 1 & 1.14 \\
\hline $\begin{array}{l}\text { AB'nin Şartları Kabul } \\
\text { Edilemez }\end{array}$ & 4 & 4.59 \\
\hline Toplam & 87 & 100 \\
\hline
\end{tabular}

Türkiye'nin Avrupa Birliği'ne girişi ağırlıklı olarak birbirine yakın oranlarda(" Bence İhtiyacımız Yok" \%33.33, "Benim İçin Fark Etmez" \%27.58, "Girmek İçin Gayret Göstermeliyiz" \%24.13) çıkması anlamlı bulunmuştur. Son zamanlarda Avrupa Birliğine giriş isteğinin ve umudunun giderek azalmaya başladığı gözlemlenmektedir. Bu tablo bir ölçüde bu durumu yansıtmaktadır. Burada bazı Avrupa Birliği ülkelerinin Türkiye'nin Avrupa Birliğine girişi ilgili olarak ortaya koydukları olumsuz tavırlarının ve çifte standartlı uygulamalarının da etkisi söz konusu olabilir.

Tablo 22: Dindarlık Durumlarına Göre Dağıllım

\begin{tabular}{|l|l|l|}
\hline Dindarlık Durumu & Kişi Sayısı & Yüzde \\
\hline Dindarım & 58 & 61.05 \\
\hline Kısmen Dindarım & 32 & 33.68 \\
\hline Dindar Değilim & 5 & 5.26 \\
\hline Toplam & $\mathbf{9 5}$ & $\mathbf{1 0 0}$ \\
\hline
\end{tabular}

Dindarlık durumunun \%61.05 oranında "dindarım", \%33.68"k1smen dindarım" şeklindeki dağılımı dindarlık düzeyinin yüksek olduğunu göstermektedir. 
Dikbıyık, C. ve Yılmaz, E. (2017).Tekirdağ Büyükşehir Naip Köyü Üzerine Bir Sosyal Yapı Araştırması. Humanitas, 5(9), 231-246

Burada \%61 civarında kişi kendisini dindar olarak görüyor, \%33'nün ise tam dindar olmasa bile belli ölçüde dini duyarlılıklara sahip olduğu söylenebilir.

Tablo 23: Günlük Hayatta Dinin Gereklerini Yaşayabilme Durumuna Göre Dağılım

\begin{tabular}{|l|l|l|}
\hline $\begin{array}{l}\text { Dinin Gereklerini } \\
\text { Yaşayabilme Durumu }\end{array}$ & Kişi Sayısı & Yüzde \\
\hline $\begin{array}{l}\text { Tam Manasıyla } \\
\text { Yaşıyorum }\end{array}$ & 37 & 40.65 \\
\hline $\begin{array}{l}\text { Tam Manasıyla } \\
\text { Yaşamıyorum }\end{array}$ & 50 & 54.94 \\
\hline Hiç Yaşayamıyorum & 4 & 4.39 \\
\hline Toplam & $\mathbf{9 1}$ & $\mathbf{1 0 0}$ \\
\hline
\end{tabular}

Gündelik hayatta dinin gereklerini tam manasıyla yaşadığını söyleyen \%41.65lik oran, tam manasıyla yaşayamasa da belli ölçüde yaşayanların oranının \%54.94 çıkması dinin gündelik hayatta büyük ölçüde pratize edildiğini veya edilme isteği bulunduğunu göstermesi açısından anlamlıdır. Yukarıda kendisini dindar olarak ifade eden $\% 61.05$ 'lik oran burada dini tam manasiyla yaşama noktasında $\% 40.65$ 'e düşmektedir. Buradaki \%61'lik oranı kuramsal dini davranış biçimi, \%21'lik farkı tolere edilebilir sapma, \%4011k bir düzeyi de gerçek dini davranış düzlemi olarak görmek mümkündür.

Tablo 24: Başka Bir Yerde Doğmak Yaşamak İsteme Durumuna Göre Dă̆llım

\begin{tabular}{|l|l|l|}
\hline İsteme Durumu & Kişi Sayısı & Yüzde \\
\hline Asla İstemezdim & 98 & 80.99 \\
\hline Olsa İyi Olurdu & 10 & 8.26 \\
\hline $\begin{array}{l}\text { Şartları Daha İyi Olan } \\
\text { Bir Yerde Doğup } \\
\text { Büyümek İsterdim }\end{array}$ & 13 & 10.74 \\
\hline Toplam & $\mathbf{1 2 1}$ & $\mathbf{1 0 0}$ \\
\hline
\end{tabular}

Naip'te yaşayanların \%81 oranında bulundukları mekândan memnun olduklarını başka bir yerde yaşamayı düşünmediklerini söyleyebiliriz. \%19 oranında köy sakininin de bulunduğu mekân ve konumdan pek memnun olmadığı başka yerlerde de yaşama isteği izhar ettiği söylenebilir.

Tablo 25: Naip Köyü Hakkındaki Düşüncelere Göre Dağılım

\begin{tabular}{|l|l|l|}
\hline $\begin{array}{l}\text { Köy Hakkındaki } \\
\text { Düşünceler }\end{array}$ & Kişi Sayısı & Yüzde \\
\hline Yaşanılabilir Bir Yer & 83 & $\mathbf{9 0 . 2 1}$ \\
\hline
\end{tabular}


Dikbıyık, C. ve Yılmaz, E. (2017).Tekirdağ Büyükşehir Naip Köyü Üzerine Bir Sosyal Yapı Araştırması. Humanitas, 5(9), 231-246

\begin{tabular}{|l|l|l|}
\hline Yaşanması Güç Bir Yer & 9 & $\mathbf{9 . 7 8}$ \\
\hline Fikrim Yok & 0 & $\mathbf{0}$ \\
\hline Toplam & $\mathbf{9 2}$ & $\mathbf{1 0 0}$ \\
\hline
\end{tabular}

Naip köyü sakinlerinin köylerini \%90 oranında yaşanabilir bir yer olarak görmesi büyük ölçüde köy yaşantısı ve ilişki biçimi ile doğal ve toplumsal çevreyle uyum içinde olduklarını gösterir. Ayrıca naip köyünün doğal güzellikleri yanında geleneksel tarım ve hayvancılık ürünlerinin sergilendiği bir Pazar konumunda olması da memnuniyeti artırıcı bir etken olarak düşünülebilir. \%10 oranında "Yaşanması Güç Bir Yer " şeklindeki memnuniyetsizlik de doğal karşılanmalıdır.

\section{Sonuç}

Köy toplumsal yapı araştırmaları bağlamında anket verileri ve gözlemlerimize dayanarak ele alıp incelediğimiz Naip köyüne ilişkin olarak vardığımız sonuçları şöyle sıralayabiliriz.

Köy nüfusunun büyük oranda (\%70) evli olduğu tespit edilmiştir. Bu da özellikle köylerde ortanın üstünde yaşlı nüfusun yaşadığı gerçeği ile paralellik göstermektedir. Daha genç nüfusun ise çeşitli nedenlerle köy dışında ve kentlerde yaşadığı bilinmektedir. Aile başına düşen çocuk sayısının da ortalama 2-3 civarında olması geleneksel batı yöresi nüfus oranıyla uyumludur.

Mesleki dağlım açısından ağırlıklı olarak \%25 çiftçi ve \%35 ev hanımı \%11 civarında esnaf ve değişik oranlarda da diğer mesleklere sahip kişilerin bulunduğu görülmüştür. Bu durum köyün kentleşme sürecine uygun olarak bir seyir takip ettiğini göstermektedir.

Eş ile tanışma biçiminin diğer yörelere göre daha serbest $(\% 50$ 'nin üstünde) ve flörtün de \%70'in üzerinde olumlandığ 1 görülmektedir. Buna karşılık boşanma oranlarında çeşitli nedenlere bağlı olarak belirgin bir artış görülmektedir.( \%44). $\mathrm{Bu}$ durumu kentlileşme sürecinin bir yansıması olarak görmek mümkündür.

Ailede karar alama süreçlerine katılım bakımından ataerkil yapının önemli ölçüde korunduğu fakat bununla birlikte annenin de belirli ölçüde karar alma süreçlerinde etkin olduğu diğer aile üyelerine karar alma süreçlerinde yeterince etkin olmadığı görülmektedir.

Gelir düzeyi bakımından köylülerin orta ve alt ve alt gelir gelir grubuna dahil oldukları görülmektedir. Buna karşıllk \%60 oranında memnun olduklarını söylemektedirler. Köy şartlarına göre gelir düzeyleri oranında memnuniyet hissettikleri söylenebilir.

Alış veriş biçimleri \%73 oranında peşin olarak yapılmaktadır. Kredi kartı kullanma oranı \%11 civarındadır. Bu tutum geleneksel köy özelliklerini yansıtması yanında yöre insanının geleneksel pazar ilişkileri içinde "garantici" karakterini göstermesi bakımından anlamlıdır. 
Köy sakinleri $\% 55$ oranında geleceğe ilişkin kaygıları olduğunu söylemelerine rağmen tasarrufu daha çok köy şartlarında üst düzey sayılabilecek kimselerin yapma eğiliminde olduğu görülmektedir. $\mathrm{Bu}$ durumu köylülerin önemli bir bölümünün gelir düzeyi bakımından düşük seviyede bulunmasıyla açıklayabiliriz. Ancak yöre insanının genellikle kendine özgü "gündelik yaşam" biçimi alışkanlığının da bu tutumda etkisi olduğu gözden uzak tutulmamalıdır.

Okuryazar oranının( \%90) büyük bir çoğunluğu ilkokul mezunu olsa bile (\%68) ülkemizin bazı yörelerine göre iyi seviyede olduğu görülmektedir. Boş zamanları değerlendirme bakımından kitap dergi gazete okuma oranı \%9 civarında iken, TV seyretmek \%31 ile ilk sırayı almaktadır. Gündelik hayatın büyük bir bölümünü işine ayıran köylüler, sınırlı ölçüdeki boş zamanlarını da köy ortamının elverdiği koşullar çerçevesinde değerlendirmektedirler.

Türkiye'nin Avrupa birliği ilişkileri bağlamında son zamanlarda ortaya çıkan olumsuz tutum köy halkına da yansımış gözükmektedir. Burada bazı Avrupa birliği ülkelerinin ve sözcülerinin Türkiye'nin Avrupa birliğine girişi ilgili olarak ortaya koydukları olumsuz tavrın etkili olduğu söylenebilir.

Dini bakımdan köy halkı her ne kadar dini tam manasıyla yaşayamadığını ifade etse de(\%41), çoğunlukla kendini dindar hissetmekte (\%61) ve dini hassasiyetlere karşı duyarlı görünmektedir.

\section{Kaynakça}

Bozkurt, Ömer(1972), Ayrımsal Sosyoloji ve Toplumsal Yap1, TODAİE Yayınları, Ankara.

Fıchter, Joseph(2002), Sosyoloji Nedir? (Çev. Nilgün Çelebi), Anı Yayınları, Ankara.

Gökçe, Birsen(2004), Türkiye'nin Toplumsal Yapısı ve Toplumsal Kurumlar, Savaş Yayınevi, 2. Basım, Ankara.

Karakaş, Mehmet (2007), Bolvadin'de Toplumsal Yap1 ve Değişim, AKÜ Sosyal Bilimler Enstitüsü Dergisi, Cilt:9, Sayı:2, Afyon.

Kıray, Mübeccel(2006), Toplumsal Yap1 Toplumsal Değişme, Bağlam Yayıncılık, 2.bask1, İstanbul.

Yılmaz, Ensar-Yusuf Avcı(2014), Bartın'ın Toplumsal Yapısı Üzerine Bir Araştırma, Detay Yayıncılık, Ankara. 